\title{
A Feasibility Study of a Teachers' Professional Development Program for Character Education in Latvia
}

Svetlana Surikova ${ }^{1}$, Manuel Joaquín Fernández González², Tamara Pigozne ${ }^{3}$, Ieva Margeviča-Grinberga ${ }^{4}$, Dita Nimante $^{5}$, Ieva Stokenberga ${ }^{6}$

1 University of Latvia, Faculty of Education, Psychology and Art, Scientific Institute of Pedagogy, 1 Imantas 7th line, LV-1083, Riga, Latvia, svetlana.surikova@lu.lv

2 University of Latvia, Faculty of Education, Psychology and Art, Scientific Institute of Pedagogy, 1 Imantas 7th line, LV-1083, Riga, Latvia, manuels.fernandezs@lu.lv

3 University of Latvia, Faculty of Education, Psychology and Art, Scientific Institute of Pedagogy, 1 Imantas 7th line, LV-1083, Riga, Latvia tamara.pigozne@lu.lv

4 University of Latvia, Faculty of Education, Psychology and Art, Department of Teachers' Education, 1 Imantas 7th line, LV-1083, Riga, Latvia, ievam@lu.lv

5 University of Latvia, Faculty of Education, Psychology and Art, Department of Educational Sciences and Pedagogical Innovations, 1 Imantas 7th line, LV-1083, Riga, Latvia, dita.nimante@lu.lv

6 University of Latvia, Faculty of Education, Psychology and Art, Department of Psychology, 1 Imantas 7th line, LV-1083, Riga, Latvia, ieva.stokenberga@lu.lv

Annotation. This article presents a feasibility study of a schoolteachers' professional development program on virtue education. Using a questionnaire and focus group discussions, the study explored program feasibility through implementors' and participants' perceptions. While participants were more critical than implementors regarding design and delivery, the overall program feasibility was high, and its main strengths and shortfalls were established. Suggestions for its improvement were put forward.

Keywords: character education, feasibility study, program adaptation, program feasibility and integrity, teachers' professional development.

\section{Introduction}

The theoretical background and methodological approach of this study are based on the recent pilot and feasibility studies (Eldridge et al., 2016; Fraser et al., 2018; Thabane 
et al., 2010), especially in the field of curriculum research (Arthur et al., 2014; Davison et al., 2014; Duerden \& Witt, 2012; Leithwood \& Montgomery, 1980), and includes the preparation, elaboration, implementation, evaluation, and improvement of professional development programs for teachers (Antoniou et al., 2011; Guskey, 2002; Jennings et al., 2011; Shukshina et al., 2016; Visser at al., 2013; Walan \& Chang Rundgren, 2014). The review of literature helped to accurately define feasibility studies and their difference with pilot studies. It was also useful for situating this study in the field of curriculum research and for deciding to adopt the methodological approach of 'self-study research'. The main findings of this theoretical analysis, which included a set of criteria for implementing the feasibility study about teachers' professional development, are presented below.

It is important to distinguish pilot studies from feasibility studies. In the field of elaboration and implementation of professional development programs for teachers, pilot studies might be useful in different regards: as a pre-survey, before conducting a program, that contributes to its development in the near future (Walan \& Chang Rundgren, 2014); to assess the program feasibility, attractiveness and preliminary evidence of efficacy (Jennings et al., 2011); to verify the effectiveness of the program and its components (Antoniou et al., 2011; Shukshina et al., 2016); and to indicate which are the problematic aspects of the program and how these difficulties can be handled (Visser at al., 2013); in short, to improve the program quality by identifying its strengths and shortfalls.

Eldridge et al. (2016) proposed a framework for distinguishing pilot studies from feasibility studies. According to this framework, 'a feasibility study asks whether something can be done, should we proceed with it, and if so, how', while 'a pilot study asks the same questions but also has a specific design feature: in a pilot study a future study, or part of a future study, is conducted on a smaller scale' (Eldridge et al., 2016, p. 1). These authors suggested to view 'feasibility as an overarching concept, with all studies done in preparation for the main study open to being called feasibility studies, and with pilot studies as a subset of feasibility studies' (ibid., p. 18). So, they concluded that 'all pilot studies are feasibility studies but not all feasibility studies are pilot studies' (ibid., p. 8). According to Thabane et al. (2010), 'pilot studies provide a good opportunity to assess feasibility of large full-scale studies' (Thabane et al., 2010, p. 9). Feasibility studies are urgently needed in the educational field for professionalizing education at all levels. Fraser et al. (2018) emphasized that

Historically, pilot and feasibility studies were not usually reported, nor were they topics of much discussion in the research literature. While to some extent this continues to be the case in educational research, pilot and feasibility studies have recently become the focus of extensive debate in the health-related literature. It would be beneficial if similar attention were given to pilot and feasibility studies in the broader research context, including the education community (p. 261).

In the field of curriculum research, in which this study is situated, 'feasibility' considers whether it is possible to run a successful program (Arthur et al., 2014) and relates to how 
successfully the program was designed and delivered (Davison et al., 2014). Leithwood and Montgomery (1980) stressed that 'an evaluation of the nature and degree of curriculum implementation may assist in making accountability and management decisions as well as serving research and development functions' (p. 194). The concept of 'program integrity', defined as the degree to which a program is implemented as originally planned, is at the core of quality implementation. An evaluation of the quality of program implementation should be based on gathering data to assess key implementation domains such as adherence, dosage, quality of delivery, and participant satisfaction (Duerden \& Witt, 2012).

For implementing a reliable feasibility study, it is important to choose a set of program assessment criteria that fit to the field explored, in this case - teachers' professional development. According to Guskey (2002), it's possible to improve teacher professional development programs using five critical levels of evaluation:

(a) participants' reactions;

(b) participants' learning;

(c) organization support and change;

(d) participants' use of new knowledge and skills; and

(e) student learning outcomes.

All these levels are important because the information gathered at each level provides relevant data for improving the quality of the professional development program (Guskey, 2002). In this study, Guskey' critical levels of evaluation were retained for structuring data collection, integrating them in the data collection instruments, and using the methodological approach of 'self-study research' (Loughran et al., 2004). Self-study is a crucial component of professional development (Hogan \& Daniell, 2015), which aims at understanding and improving teaching, learning, and research practice and uses a multiplicity of approaches, including 'collaborative self-study' (Clift et al., 2005; Han et al., 2014; Malmqvist et al., 2019), 'collective self-study' (Lunenberg \& Samaras, 2011) or 'interactive exploration of an issue by a team of researchers' (ibid., p. 844). Self-study research includes five methodological components:

(a) personal situated inquiry;

(b) critical collaborative inquiry;

(c) improved learning;

(d) transparent and systematic research process; and

(e) knowledge generation and presentation (Samaras, 2010, pp. 72-73).

As regards the relevance and originality of the program addressed by this study, scholarly literature has often addressed diverse aspects of teachers' professional development in multiple settings and contexts from theoretical and empirical perspectives (e.g., Antoniou et al., 2011; Appova \& Arbaugh, 2018; Beavers, 2009; Gorozidis \& Papaioannou, 2014; Gregson \& Sturko, 2007; Guskey, 2002; Jennings et al., 2011; Shukshina et al., 2016, Šarić \& Šteh, 2017; Van Eekelen et al., 2006; Visser et al., 2013, etc.). However, during the last decade, only a few teacher-training programs (Character.org, n.d.; The Jubilee Centre, 2020) and empirical studies have focused on in-service teachers' professional 
development for implementing holistic character education at school (Fullard \& Watts, 2020; Ledford, 2011; Midgette et al., 2018; Walker et al., 2017).

As in other countries, in Latvia there is a need for innovative high-quality teachers' professional development programs for character education which adopt innovative approaches and methods for meeting the challenges and demands of contemporary schools and society. In order to respond to this need, in 2018-2019 a team of academics and practitioners and policy makers from Latvia, Estonia and Spain elaborated the transnational teacher training program 'Arete catalyst' (in Greek, it means 'facilitator of character') (Arete Catalyst, 2019; Fernández González et al., 2020). The program was based on the theoretical framework for character education in schools (The Jubilee Centre, 2017) and on a preliminary research of best practices, expectations, and needs in the field of character education in those countries (Surikova \& Pigozne, 2018; Surikova et al., 2020; Verdeja Muñiz \& García-Sampedro Fernández-Canteli, 2018), which was carried out within the Erasmus+ project 'Supporting teachers for developing intra-personal competencies and character education at school - Arete Catalyst'. In 2019, this program was adapted to the socio-cultural context of Latvia (Fernández González et al., 2020) and piloted by the University of Latvia as a professional competence development program called 'Improving pedagogues' transversal competencies for promoting students' character education and excellence' (see Appendix). This is the program whose feasibility is explored in this study (hereinafter: the Program).

The socio-cultural adaptation of teachers' professional development programs is a challenging process. Efficient transfer of teachers' professional development should be viewed in a systemic manner (Broad, 2005), which includes considering the program relevance for the teachers and the socio-cultural community, as well as the enablers and eventual obstacles of transfer and the ways of dealing with them (McDonald, 2001).

Why is teacher training for character education relevant nowadays? Character education, understood as the facilitation of students' acquisition of moral virtues, is widely recognized as an essential part of school education in the $21^{\text {st }}$ century (e.g., Bialik et al., 2015; Fullard \& Watts, 2020; Retnowati et al., 2018; Walker et al., 2017). In this study, a character is defined as 'a set of personal traits or dispositions that produce specific moral emotions, inform motivation and guide conduct' (The Jubilee Centre, 2017, p. 2). Character education includes explicit and implicit educational activities that help people to develop virtues (Harrison et al., 2016; The Jubilee Centre, 2017). Virtues are moral habits that enable human beings to give an appropriate ethical response to situations in any area of experience and that sustain a well-rounded life and a thriving society (The Jubilee Centre, 2017).

For implementing character education effectively, a good teacher needs to possess not only subject knowledge and skills, but also a good character and good sense (Arthur et al., 2005 , 2018). Character strengths, such as kindness, fairness, curiosity, open-mindedness and critical thinking, are substantial for a good teacher, and therefore pre-service and 
in-service teachers should be stimulated to build upon these strengths to become good role models for their pupils (Gradišek, 2012; Šarić \& Šteh, 2017). Furthermore, 'emphasis on moral character is needed throughout a teacher's career' and has to be reflected in teachers' professional development programs (Arthur et al., 2015, p. 29).

This study is relevant as an academic response to the need for reliable and feasible teacher training programs in the field of character education and the challenges of program adaptation. As regards the implementation of the study and its challenges, the study was implemented by a team of researchers (four program implementors and two external experts) who investigated the feasibility of the Program in order to refine its design and delivery. In Spring 2019 they conducted a feasibility study, exploring implementors' and participants' beliefs about the strengths and shortfalls of the Program, and proposing ways to improve it. The study faced the challenge of teachers' (participants') lack of time for deepening their understandings of character education due to an overloaded school curriculum, which focuses on the pupils' competitive acquisition of knowledge and skills and pays little attention to the development of pupils' and teachers' own character.

\section{Research methodology}

The aim of the study was to establish the feasibility of a teacher training program for character education. The research question that guided this feasibility study was: What was the overall feasibility of the Program according to program participants and implementors? This question was split into two sub-questions, the first one addressing the quantitative assessment and the second one - the qualitative comments about Program feasibility.

Research sub-question 1 (RQ1): How participants and implementors have rated the Program feasibility? Were there any differences between respondent groups?

Research sub-question 2 (RQ2): Which were the strengths and shortfalls of the Program feasibility according to respondents?

\section{Research sample}

The participants in the Program were recruited by the Education, Culture, and Sports Department of the Riga City Council (the leading partner of the Erasmus+ project 'Arete Catalyst'). They all were in-service teachers from a single public school $(\mathrm{n}=24: 22$ females, 2 males). The Program was implemented by academic staff from the University of Latvia $(\mathrm{n}=4$ : females) holding a PhD in Pedagogy or Psychology and with a large experience in leading pre-service and in-service teacher training. 


\section{Procedure of implementing the Program}

The Program (see Appendix) was implemented as a 4-day intensive training during the Spring break in March 2019 (3 days) and in May 2019 (1 day, final assessment). The Program included seminars, lectures, and six practical activities, which were integrated with the related seminars and lectures. It was delivered in direct presence modality at the participants' school for convenience reasons. After the first 3-day session, participants were given two months for designing and implementing a final project in character education. Participants were assessed based on their active participation in the program activities and the quality of the design, implementation, and presentation of the final project. After completion of the Program, the participants received a certificate delivered by the University of Latvia.

\section{Research methods and data collection instruments}

The study used mixed methods for addressing the research question: the results of the initial quantitative assessment of the Program feasibility were nuanced using a comparative triangulation with respondents' qualitative open comments about strengths and shortfalls of the program feasibility.

For collecting data, at the end of the piloting of the Program, participants and implementors were asked to complete an anonymous questionnaire (Table 1) containing both closed-ended questions (4-point Likert scale) and open-ended questions. The feasibility of the program was assessed through the lens of six general aspects (focus, clarity of the goal, materials, methodology, usefulness, and recommendableness) and four key components (learning outcomes, structure, activities, and length) of the program. This approach to program feasibility assessment captured the five levels of Guskey's model for professional development program evaluation (Guskey, 2002; Visser et al., 2013), namely, participants' reactions (question 10), participants' learning (questions 2, 3, 7 and 8), organization support and change (question 4 and 6), participants' use of new knowledge and skills (question 5 and 9), and student learning outcomes (question 1).

A collaborative or collective self-study approach (Clift et al., 2005; Han et al., 2014; Lunenberg \& Samaras, 2011; Malmqvistet et al., 2019) was adopted for data analysis and interpretation of results involving four program implementors and two external experts. Primary data processing methods (for obtaining the descriptive statistics) and secondary data processing methods (for obtaining the inferential statistics) were implemented using IBM SPSS Statistics 22 software, The Cronbach's Alpha Reliability Test was used to assess the internal consistency strength of the questionnaire items, which was high $(\alpha=.924)$. Taking into account the small size of the samples, the program participants' and implementors' perceptions were compared using Mann-Whitney U non-parametric test based on the requirements for small samples (Billiet, 2003; Mehta \& Patel, 2012; Nachar, 2008). 
Table 1

Feasibility Criteria (Key Components and General Aspects) Included in the Questionnaire

\author{
Program description included Questions (codes) \\ in the questionnaire
}

Assessment of the key components of the program

Scale: 1 = absolutely disagree; $2=$ rather disagree; $3=$ rather agree; $4=$ absolutely agree

1. The program addressed eight 1 . Do you agree with the following statement? The learnintended learning outcomes ing outcomes of the program are appropriate (useful). (ILOs) within three dimensions: ( $\left.k c 1 \_I L O s\right)$.

1) knowledge; 2) skills; and 3) competence.

2. The program included four modules (communication, theory and self-understanding, methodology, assessment).

3. The program included three kinds of activities (lectures, seminars and practical works).

4. The length of the program was $36 \mathrm{~h}$.

2. Do you agree with the following statement? The structure of the program is appropriate. (kc2_structure).

3. Do you agree with the following statement? The kind of activities of the program is appropriate (helpful). ( $k c 3_{-}$ activities).

4. Do you agree with the following statement? The length of the program is appropriate (convenient). ( $k c 4$ length)

Please, make some comments or suggestions about your answers.

Assessment of the general aspects of the program

Scale: 1 = absolutely disagree; 2 = rather disagree; 3 = rather agree; 4 = absolutely agree

Please, read the following state- 5 . The focus of the program is relevant in my professional ments and think how much you context (gal_focus).

agree or disagree. There are no 6 . From the beginning I had a clear picture of the program right or wrong answers, so just an- goal (ga2_prior_understanding).

swer honestly how do you think. 7. The materials of the program were appropriate (ga3 study_aids).

8. The methodology of the program was appropriate (ga methodology).

9. The program enhanced the quality of my professional practice (ga5_better_practice).

10. I would recommend this program to my colleagues (ga6_I_recommend).

Please, make some comments or suggestions about your answers.

Please, add any other comments or suggestions.

Note. Some new general aspects and corresponding codes were added conducting the qualitative data analysis (e.g., recruitment of the potential participants (ga7_recruitment); participants' motivation and participation (ga8_motivation); the program sustainability (ga9_sustainability)). 
According to Billiet (2003), at the level of significance 5\% ( $p=.05)$, for the participants' sample $(n=20)$ and the implementors' sample $(n=4)$, the critical U-value for the Mann-Whitney U test was 14.0. This critical U-value and Exact Test statistics were used to determine statically significant differences between two respondent groups and then a measure of effect size for statically significant differences was calculated and interpreted (Cohen, 1992; Lenhard \& Lenhard, 2016).

\section{Results}

In this section, the quantitative research findings about the Program feasibility are presented first (RQ1), and then respondents' qualitative open comments about strengths and shortfalls of the Program feasibility are presented (RQ2), using comparative triangulation of results.

RQ1: How participants and implementors have rated the Program feasibility? Were there any differences between respondent groups?

Twenty participants and four implementors completed the questionnaires on paper. Overall, most respondents absolutely agreed $\left(M_{o}=4\right.$ in a 4 -point Likert scale) that the focus and length of the Program were appropriate and rather agreed $\left(M_{o}=3\right)$ that the methodology, materials, activities, and intended learning outcomes (ILOs) were relevant. Most respondents rather agreed $\left(M_{o}=3\right)$ that the Program had enhanced the quality of their professional practice (ga5_better_practice) and they would recommend it to their colleagues (ga6_I_recommend) (see Table 2). 


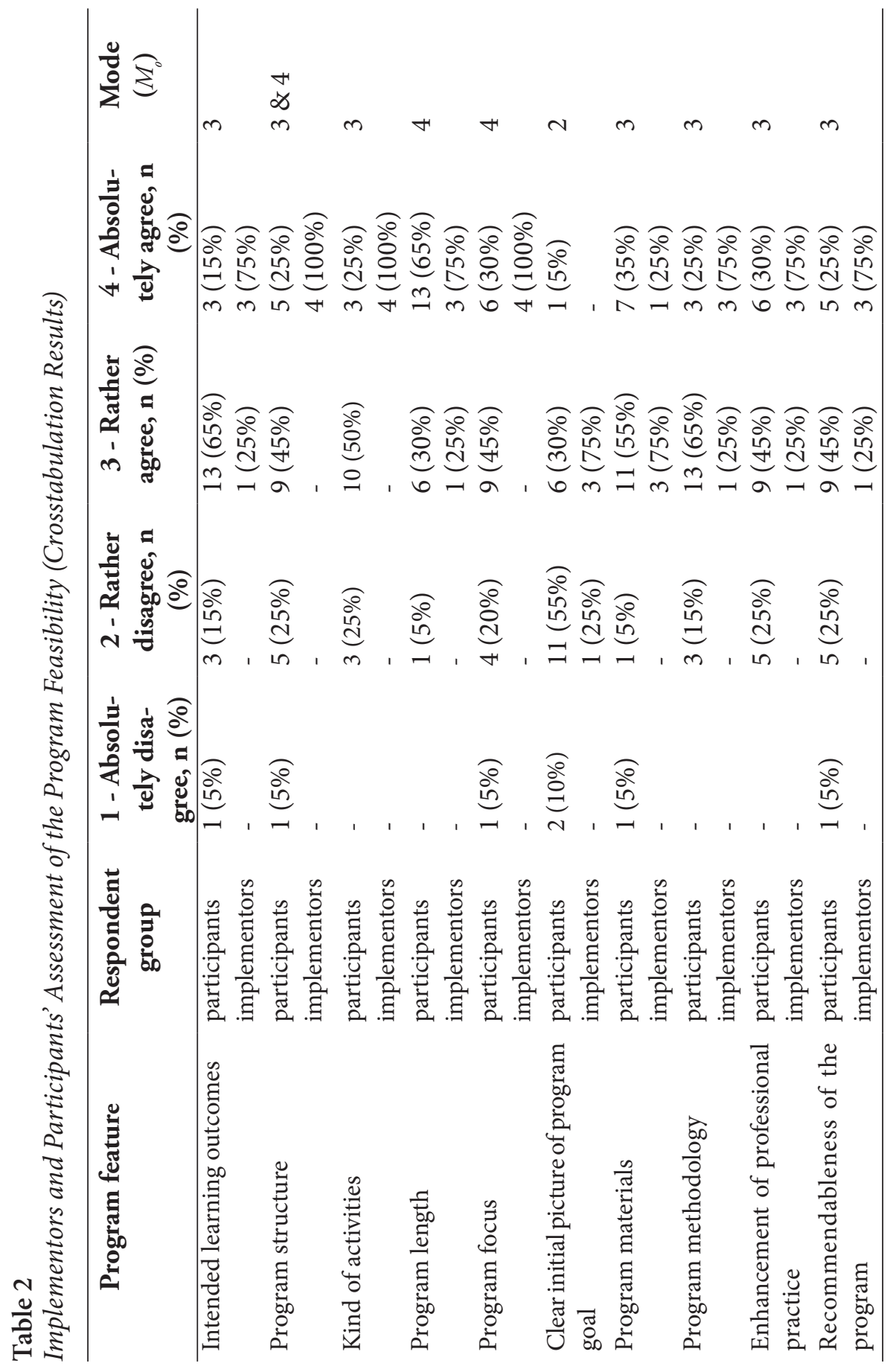


The majority of participants rather agreed, and the majority of implementors absolutely agreed, on the relevance of seven program features (ILOs, structure, kind of activities, focus, methodology, enhancement of professional practice and recommendableness of the program) out of the ten proposed for evaluation. The length of the Program was rated as appropriate, and the program materials were rated as rather appropriate by most of both participants and implementors. However, $55 \%$ of the participants had a rather unclear initial picture of program goal (Table 2), as illustrated by a participant's comment: 'The Program is interesting but there were no clear objectives and results to be achieved from the beginning'.

As regards the differences between respondent groups, it should be noted that implementors assessed higher than participants all the key components and general aspects of the Program (excluding the program materials (ga3_study_aids)). This difference was statistically significant with a medium and large effect regarding the program ILOs, structure, activities and focus $(U=10.0-14.0, p=.018-.045, r=.046-.051)$ (see Table 3).

\section{Table 3}

Differences Between Implementors and Participants' Assessment of the Program Feasibility (Mann-Whitney U-Test Results)

\begin{tabular}{|c|c|c|c|c|c|}
\hline Program feature & $\begin{array}{l}\text { Respondent } \\
\text { group }\end{array}$ & $\begin{array}{c}\text { Mean } \\
\text { rank }\end{array}$ & $\begin{array}{l}\text { Sum of } \\
\text { ranks }\end{array}$ & U-value & Exact Sig. \\
\hline \multirow[t]{2}{*}{ Intended learning outcomes } & participants & 11.20 & 224.00 & 14.0 & .045 \\
\hline & implementors & 19.00 & 76.00 & & \\
\hline \multirow[t]{2}{*}{ Program structure } & participants & 11.00 & 220.00 & 10.0 & .018 \\
\hline & implementors & 20.00 & 80.00 & & \\
\hline \multirow[t]{2}{*}{ Kind of activities } & participants & 11.00 & 220.00 & 10.0 & .018 \\
\hline & implementors & 20.00 & 80.00 & & \\
\hline \multirow[t]{2}{*}{ Program length } & participants & 12.28 & 245.50 & 35.5 & .737 \\
\hline & implementors & 13.63 & 54.50 & & \\
\hline \multirow[t]{2}{*}{ Program focus } & participants & 11.10 & 222.00 & 12.0 & .029 \\
\hline & implementors & 19.50 & 78.00 & & \\
\hline \multirow{2}{*}{$\begin{array}{l}\text { Clear initial picture of pro- } \\
\text { gram goal }\end{array}$} & participants & 11.73 & 234.50 & 24.5 & .241 \\
\hline & implementors & 16.38 & 65.50 & & \\
\hline \multirow[t]{2}{*}{ Program materials } & participants & 12.55 & 251.00 & 39.0 & .970 \\
\hline & implementors & 12.25 & 49.00 & & \\
\hline \multirow[t]{2}{*}{ Program methodology } & participants & 11.33 & 226.50 & 16.5 & .068 \\
\hline & implementors & 18.38 & 73.50 & & \\
\hline \multirow{2}{*}{$\begin{array}{l}\text { Enhancement of profession- } \\
\text { al practice }\end{array}$} & participants & 11.48 & 229.50 & 19.5 & .115 \\
\hline & implementors & 17.63 & 70.50 & & \\
\hline \multirow{2}{*}{$\begin{array}{l}\text { Recommendableness of the } \\
\text { program }\end{array}$} & participants & 11.35 & 227.00 & 17.0 & .081 \\
\hline & implementors & 18.25 & 73.00 & & \\
\hline
\end{tabular}




\section{RQ2: Which were the strengths and shortfalls of the Program feasibility according to respondents?}

The analysis of the program feasibility was completed by exploring the strengths and shortfalls of the Program in respondents' answers to the open-ended questions. In the presentation of qualitative results (Table 4), a reference to the respective quantitative coding was added for facilitating subsequent triangulation of results.

\section{Table 4}

The Respondents' Expressions Evaluating the Implementation of the Program

\begin{tabular}{|c|c|}
\hline According to participants & According to implementors \\
\hline \multicolumn{2}{|c|}{ Strengths and opportunities of the program implementation } \\
\hline \multirow{2}{*}{$\begin{array}{l}\text { Comment } 1 \text { : I think it is important for professionals } \\
\text { working with children to be reminded of the need to } \\
\text { take care of themselves, because the ability to renew } \\
\text { one's resources is also a part of character education; } \\
\text { so in general I think it was very useful that this topic } \\
\text { was discussed ( } \mathrm{ga1} \text { focus). }\end{array}$} & $\begin{array}{l}\text { Comment 8: Practical activities were o } \\
\text { everyone was invited to get involved }(k c 3\end{array}$ \\
\hline & $\begin{array}{l}\text { Comment 9: It was positive that the whole school } \\
\text { team (ga7_recruitment) had the opportunity to } \\
\text { cooperate and be actively involved ( } k c 3 \text { _activities). }\end{array}$ \\
\hline \multirow{2}{*}{$\begin{array}{l}\text { Comment 2: There were many valuable/useful meth- } \\
\text { ods (ga4_methodology). } \\
\text { Comment 3: I'll be able to use new upbringing methods } \\
\text { in my work (ga4_methodology; ga5_better_practice). }\end{array}$} & $\begin{array}{l}\text { University of Latvi } \\
\text { teachers' professi }\end{array}$ \\
\hline & \\
\hline $\begin{array}{l}\text { In my work (ga4_methodology; gab_better_practice). } \\
\text { Comment } 4 \text { : Our school teachers had a great op- } \\
\text { portunity to improve their approaches to character } \\
\text { education (ga4_methodology; ga5_better_practice). }\end{array}$ & $\begin{array}{l}\text { Comment 11: Different useful approaches and } \\
\text { strategies were introduced to teachers to facilitate } \\
\text { character education at their school successfully } \\
\text { (ga4_methodology). }\end{array}$ \\
\hline
\end{tabular}

Weaknesses, threats, and challenges of the program implementation

Comment 5: The program is interesting (gal_focus) but there are no clear objectives and results to be achieved (ga2_prior_understanding).

Comment 6: The participants could be informed about the independent works to be done already in the first session (ga2_prior_understanding), so that everyone can practically think up about the theory in terms of applicability (ga5_better_practice). There were some concerns about the time necessary to choose, elaborate, and evaluate classroom materials on character education (ga3_study_aids; ga4_methodology).

Comment 7: I find valuable for my lessons only a few methods used in the program. Since I am not a class teacher yet, I can't use much of those methods during my subject lessons (ga4_methodology; ga5_ better_practice).
Comment 12: If the participants had come from different educational institutions, it would have been possible to get more diverse experiences (ga7_recruitment).

Comment 13: Not all participants attended the project presentation during the final session (ga8_motivation).

Comment 14: The participants' initial motivation for participating in the piloting of the professional competence development program wasn't studied in depth. Participants' willingness to participate was quite diverse, making it difficult to evaluate the program itself (ga8_motivation).

Comment 15: The effect which was intended by putting the communication module at the beginning of the program did not really happen (kc2_structure). 
In the open questions, in-service teachers mentioned several strengths (e.g., renewing resources, useful new methods) and shortfalls (e.g., lack of clear objectives and of information about the expected independent work) of the Program (Table 4, comments 1-7). In their turn, the implementors also mentioned several pros (e.g., participants' involvement, work in the school team, program sustainability) and cons (diverse motivation level of participants and lack of diversity in the recruitment) (Table 4, comments 8-14). As regards this last point (diversification of participants' recruitment), it should be noted that, on the one hand, the fact that the whole school team had the opportunity to participate together in the program activities was considered to be positive (comment 9), but, on the other hand, if the participants had come from different educational institutions, it seems that it would have allowed for more diverse and enriching experiences (comment 12). These results should be considered in the recruitment of future participants.

Triangulating the results of the analysis of qualitative (qual) data (Table 4) with the quantitative (quan) results, it appeared that the main strengths of the program referred to the opportunities provided by the innovative methodology (quan \& qual) as well as its appropriate duration (quan), relevant materials (quan), activities (quan \& qual), ILOs (quan), and sustainability (qual). The program shortfalls were related mainly to a lack of initial clarity about the program expected results (quan \& qual) and to an unequal motivation level of participants (qual).

\section{Discussion of results}

This study showed that the Program that was analyzed had overall high feasibility. In this section, some of the most relevant research results supporting this conclusion were discussed in the light of theoretical and empirical studies conducted previously.

The program feasibility aspect that was most often highlighted by respondents was its high practical usefulness, which was apparent in the kind of activities proposed, the materials, and methodology used, and which enhanced participants' professional practice. The majority of participants (75\%) agreed or rather agreed that the focus of the Program was relevant in their professional context and the Program enhanced the quality of their professional practice. This finding echoes the claim of adult learning theory that in-service teachers as adult learners are motivated to learn if what they learn will be directly and immediately applicable to their practice (Beavers, 2009; Gregson \& Sturko, 2007; Knowles et al., 2005). This finding is also consistent with recent empirical research (Fullard \& Watts, 2020) which found that ' $[$...] teachers value continuing professional development that includes practical elements, such as resources and opportunities to engage with and learn from experts in the field' (p. 11).

A certain percentage of participants (55\%) regretted that they had a rather unclear initial picture of the Program goal. This reaction is comprehensible in the light of 
scientific literature, which emphasizes that 'the purpose and benefit for a specific teacher professional development should be made clear and concrete' because 'teachers need to see the application for their practice in order to be active participants' (Beavers, 2009, p. 27). The feasibility study also revealed that participants had different levels of motivation, which made it difficult to assess the Program. This finding is in line with the studies revealing considerable differences among teachers in their motivation to learn due to diverse internal and external factors (Appova \& Arbaugh, 2018; Gorozidis \& Papaioannou, 2014; Šarić \& Šteh, 2017; Van Eekelen et al., 2006). These findings should be considered when implementing the Program in the future, particularly introducing the Program to future participants.

The study revealed also that Program participants (i.e., in-service teachers as adult learners) were more critical than implementors (i.e., university academics as adult educators) regarding all the main features of the Program (excepting the program materials). This finding confirms that it is a real challenge to design and deliver such kind of teachers' professional development program which would be fully useful and appropriate to all participants because 'teachers have different needs [...], practice is unique for each teacher with each class', and therefore 'diversity and healthy disagreement' should be appreciated (Beavers, 2009, p. 29) and perceived as a factor enabling to be flexible in elaborating and implementing a new program. A possible explanation for the differences between two respondent groups (implementors and participants) regarding the feasibility level of the Program could be their initial diverse knowledgeability of the field: it could be argued that implementors, being more knowledgeable, could appreciate better than participants the quality of the Program ILOs, structure, activities, and focus. But more research would be necessary to verify this hypothesis.

\section{Recommendations}

For the elaboration of the recommendations for improving the Program feasibility, the research results were presented and discussed in two focus group discussions organized in June 2019 (Riga, Latvia) and in October 2019 (Oviedo, Spain), involving external experts and the implementors of the Program. The following suggestions for improving the Program feasibility were put forward (Table 5). 
Table 5

Expert Suggestions for Improving the Program Feasibility

\section{Program feasibility Integrity Suggestions for improving the feature and feasibility program feasibility}

\begin{abstract}
Program introduction: Before starting the piloting, a short description of the program was sent to the participating school leading staff via email. The program was introduced to participants by the program director immediately after the communication module.
\end{abstract}

Structure: The communication module was delivered before the theory and self-understanding module for facilitating the emergence of a collaborative learning community from the very beginning of the program. The decision to put the communication module as the first to be implemented was driven by the importance to build a warm, collaborative atmosphere where diverse opinions are welcomed and emphatic, non-judgmental communication style is accepted.

Assessment: The assessment of the program was based on the participation in program activities and on the design, implementation, and presentation of the final project in character education without any limitations related to its focus.

High integrity, aver- To introduce clearly and concretely the proage feasibility gram objective and expected results from the beginning of program implementation.

High integrity, aver- To be flexible when deciding the sequence age feasibility of modules and related activities accordingly. It was suggested that, for participants having a dominant instructional learning/ communication style, it would be better to start with the theory and self-understanding module, but for participants with a dominant collaborative learning/communication style, it would be appropriate to start the program with the communication module. An online application form could be elaborated and used to investigate the participants' preferences and expectations.

Average integrity, high feasibility
To help participants to be more concrete in the definition of the final projects within the module 'Assessment', for example, focusing only on one aspect of character education (e.g., one virtue).

To be elastic regarding the elaboration of the final project: Younger teachers could be asked to elaborate and implement a completely new character education project, while experienced teachers could be allowed to 'revisit' one of the projects or activities they have implemented in the past from the perspective of character education, instead of creating a new project. 


\begin{tabular}{|c|c|c|}
\hline $\begin{array}{c}\text { Program feasibility } \\
\text { feature }\end{array}$ & $\begin{array}{c}\text { Integrity } \\
\text { and feasibility }\end{array}$ & $\begin{array}{c}\text { Suggestions for improving the } \\
\text { program feasibility }\end{array}$ \\
\hline $\begin{array}{l}\text { Materials: All the materials } \\
\text { used and/or presented during } \\
\text { the program delivery were } \\
\text { available in paper format and } \\
\text { via email in electronic format. }\end{array}$ & $\begin{array}{l}\text { Average integrity, } \\
\text { high feasibility }\end{array}$ & $\begin{array}{l}\text { To create an online base of methodological } \\
\text { materials summarizing the examples of good } \\
\text { practice in character education shared by } \\
\text { the program implementors and participants } \\
\text { (their final projects). }\end{array}$ \\
\hline $\begin{array}{l}\text { Activities: All the seminars and } \\
\text { lectures were delivered in direct } \\
\text { presence modality at the partic- } \\
\text { ipants' school for convenience } \\
\text { reasons. The six practical works } \\
\text { were integrated with the related } \\
\text { seminars and lectures and were } \\
\text { implemented in the workplace } \\
\text { (presence modality). }\end{array}$ & $\begin{array}{l}\text { Average integrity, } \\
\text { high feasibility }\end{array}$ & $\begin{array}{l}\text { To improve the delivery of the program by } \\
\text { using more intensively the e-environment } \\
\text { opportunities (e.g., Moodle), at least in some } \\
\text { of the modules. }\end{array}$ \\
\hline $\begin{array}{l}\text { Delivery time: The Program was } \\
\text { implemented as a 4-day inten- } \\
\text { sive training session during the } \\
\text { Spring break in March } 2019 \\
\text { ( } 3 \text { ays) and in May } 2019 \text { ( } 1 \text { day, } \\
\text { final assessment). }\end{array}$ & $\begin{array}{l}\text { High integrity, aver- } \\
\text { age feasibility }\end{array}$ & $\begin{array}{l}\text { To offer the program delivery in Janu- } \\
\text { ary-March instead of March-May, because } \\
\text { at the end of the academic year in-service } \\
\text { teachers might be very busy, overloaded, } \\
\text { and tired. }\end{array}$ \\
\hline
\end{tabular}

Reflecting on these suggestions (Table 5), it was found that program integrity (i.e., the degree to which a program is implemented as originally planned) and program feasibility (i.e., the relevance, appropriateness of its features) were not necessarily connected: a high level of program integrity, which is at the core of quality implementation, might not always be tied to a high level of program feasibility. And conversely, a high level of program feasibility, which is at the core of implementation successfulness, might not always be tied to a high level of the program integrity. Improving the flexibility of program design and delivery is one of possible solutions to keep a balance between the program integrity and feasibility.

Summarizing the main suggestions (Table 5), future implementors should ensure participants' voluntariness and should be flexible in implementing the Program, taking into consideration the specificity of participants. For example, making a flexible choice of delivering modality, place, time, and dosage (how often, how many hours per day), adapting the sequence of modules and related activities to participants' dominant learning and communication styles, negotiating with them from the beginning the requirements for the elaboration of the final projects, etc. 


\section{Conclusion}

This study explored the feasibility of a teacher training program for character education through the lens of implementors' and participants' perceptions. The analysis of the quantitative and qualitative data, which was conducted as a collaborative self-study involving four implementors and two external experts, revealed that the majority of respondents were satisfied with the feasibility of the Program, in particular with its materials, activities, ILOs, methodology, length, and sustainability. Therefore, it could be concluded that such program could be proposed to in-service teachers interested in implementing character education at school.

In order to enhance program feasibility, some improvements might be introduced regarding several aspects such as diversifying participant recruitment, considering their initial motivation, adapting the program structure to their preferences, using e-environment opportunities, and choosing a better delivery time. Program flexibility could be a good solution to keep a balance between the program integrity and feasibility.

The findings of this study can be weighed in light of its limitations. This study does not address the question of whether the new Program enhances in-service teachers' professional competence in the field of character education and their personal flourishing, but it explores implementors' and participants' perceptions of the program feasibility and reveals the complex connections between program feasibility and integrity.

Some of the limitations of this study could be addressed in future research. First, the study focused on the program delivery involving in-service teachers from a single school; and second, only one data collection method was employed (a questionnaire). In future research, it could be useful to explore not only the feasibility but also the effectiveness of the program in different settings, for instance, using pre- and post-testing and involving the teachers from different schools. Furthermore, the reliability of the study could be enhanced also by diversifying data collection methods, for example, using in-depth interviews with participants. The long-term impact of the program could be explored using a longitudinal study. Further work directions could also include the refining of the Latvian program based on the practical implications of the findings of this study, especially the suggestions for improving the program design and delivery.

\section{Acknowledgments}

This work was supported by the EC Erasmus+ under Grant No 2017-1-LV01KA201-035435; the EU European Regional Development Fund under Grant No 1.1.1.2/ VIAA/1/16/071 (the post-doctoral project 'Arete school') and the University of Latvia under Grant No ZD2010/AZ22 (the research project 'Human, technologies, and quality of education'). 


\section{Disclosure statement}

No potential conflict of interest was reported by the authors.

\section{References}

Antoniou, P., Kyriakides, L., \& Creemers, B. (2011). Investigating the effectiveness of a dynamic integrated approach to teacher professional development. Center for Educational Policy Studies, 1(1), 13-41. https://www.cepsj.si/index.php/cepsj/article/view/439/255

Appova, A., \& Arbaugh, F. (2018). Teachers' motivation to learn: Implications for supporting professional growth. Professional Development in Education, 44(1), 5-21. https://doi.org/10. $\underline{1080 / 19415257.2017 .1280524}$

Arete Catalyst. (2019). 'Arete catalyst': Teacher training program for enhancing pupils' flourishment at school (Intellectual output No 2). https://www.pzi.lu.lv/fileadmin/user upload/lu portal/ projekti/pzi/ARETE/Arete Catalyst Programme EN.pdf

Arthur, J., Davison, J., \& Lewis, M. (2005). Professional values and practice: Achieving the standards for QTS. Routledge Falmer.

Arthur, J., Harrison, T., Kristjánsson, K., Davison, I., Hayes, D., \& Higgins, J. (2014). My character enhancing future-mindedness in young people: A feasibility study. The Jubilee Centre for Character and Virtues at the University of Birmingham. https://issuu.com/d.s.hayes/docs/ my character pdf final

Arthur, J., Kristjansson, K., Cooke, S., Brown, E., \& Carr, D. (2015). The good teacher: Understanding virtues in practice. The Jubilee Centre for Character and Virtues at the University of Birmingham. https://www.jubileecentre.ac.uk/userfiles/jubileecentre/pdf/ Research\%20Reports/The Good Teacher Understanding Virtues in Practice.pdf

Beavers, A. (2009). Teachers as learners: Implications of adult education for professional development. Journal of College Teaching \& Learning, 6(7), 25-30. https://core.ac.uk/download/ pdf/268110468.pdf

Bialik, M., Bogan, M., Fadel, C., \& Horvathova, M. (2015). Character education for the 21st century: What should students learn? Center for Curriculum Redesign. https://curriculumredesign. org/wp-content/uploads/CCR-CharacterEducation_FINAL 27Feb2015.pdf

Billiet, P. (2003). The Mann-Whitney U-test - analysis of 2-between-group data with a quantitative response variable. http://psych.unl.edu/psycrs/handcomp/hcmann.PDF

Broad, M. L. (2005). Beyond transfer of training: Engaging systems to improve performance. Pfeiffer. Character.org. (n.d.). 11 principles workshops. https://www.character.org/11-principles-workshops

Clift, R. T., Brady, P., Mora, R. A., Choi, S. J., \& Stegemoller, J. (2005). From self-study to collaborative self-study to collaborative self-study of collaboration: The evaluation of the research team. In C. Kosnik, C. Beck, A. R. Freeze, \& A. P. Samaras (Eds.), Making a difference 
in teacher education through self-study: Studies of personal, professional and program renewal (pp. 85-100). Springer.

Cohen, J. (1992). A power primer. Psychological Bulletin, 112(1), 155-159. https://doi. org/10.1037/0033-2909.112.1.155

Davison, I., Harrison, T., Hayes, D., \& Higgins, J. (2014). My character pilot and feasibility cluster randomised trial. The Jubilee Centre for Character and Virtues at the University of Birmingham. http://www.jubileecentre.ac.uk/userfiles/jubileecentre/pdf/My\%20 Character\%20PDFs/my-character-rct-report-final.pdf

Duerden, M. D., \& Witt, P. A. (2012). Assessing program implementation: What it is, why it's important, and how to do it. Journal of Extension, 50(1). https://www.joe.org/joe/2012february/ a4.php

Eldridge, S. M., Lancaster, G. A., Campbell, M. J., Thabane, L., Hopewell, S., Coleman, C. L., \& Bond, C. M. (2016). Defining feasibility and pilot studies in preparation for randomised controlled trials: Development of a conceptual framework. PLoS One, 11(3), 1-22. https://doi. org/10.1371/journal.pone.0150205

Fernández González, M. J., Pigozne, T., Verdeja Muñiz, M., Säre, E., \& Surikova, S. (2020). Designing a teacher training programme for character education: An international partnership. In V. Lubkina, K. Laganovska, A. Kḷavinska, \& A. Strode (2020). Society. Integration. Education. Proceedings of the International Scientific Conference, 22-23 May, 2020, Vol. 5 (pp. 72-88). Rezekne. Academy of Technologies. http://dx.doi.org/10.17770/sie2020vol5.5171

Fernández González, M. J., Surikova, S., \& Pigozne, T. (2020). Adaptation of a teacher training programme for character education to the Latvian context. In L. Daniela (Ed.), Human, technologies and quality of education, 2020 (pp. 7-18). The University of Latvia Press. https:// doi.org/10.22364/htqe.2020.01

Fraser, J., Fahlman, D., Arscott, J., \& Guillot, I. (2018). Pilot testing for feasibility in a study of student retention and attrition in online undergraduate programs. The International Review of Research in Open and Distributed Learning, 19(1), 260-278. https://doi.org/10.19173/irrodl. v19i1.3326

Fullard, M., \& Watts, P. (2020). Leading character education in schools: An online CPD programme. Jubilee Centre for Character and Virtues, University of Birmingham. https:// www.jubileecentre.ac.uk/userfiles/jubileecentre/pdf/Research\%20Reports/CPD Report.pdf

Gorozidis, G., \& Papaioannou, A. G. (2014). Teachers' motivation to participate in training and to implement innovations. Teaching and Teacher Education, 39, 1-11. https://doi.org/10.1016/j. tate.2013.12.001

Gradišek, P. (2012). Character strengths and life satisfaction of Slovenian in-service and preservice teachers. Center for Educational Policy Studies, 2(3), 167-180. https://www.cepsj.si/ index.php/cepsj/article/view/379/207

Gregson, J. A., \& Sturko, P. A. (2007). Teachers as adult learners: Re-conceptualizing professional development. MPAEA Journal of Adult Education, 36(1), 1-18. https://files.eric.ed.gov/fulltext/ EJ891061.pdf 
Guskey, T. R. (2002). Does it make a difference? Evaluating professional development. Educational Leadership, 59(6), 45-51. http://www.ascd.org/publications/educational-leadership/mar02/ vol59/num06/Does-It-Make-a-Difference\%C2\%A2-Evaluating-Professional-Development. aspx

Han, H. S., Vomvoridi-Ivanović, E., Jacobs, J., Karanxha, Z., Lypka, A., Topdemir, C., \& Feldman, A. (2014). Culturally responsive pedagogy in higher education: A collaborative selfstudy. Study Teacher Education, 10(3), 290-312. https://doi.org/10.1080/17425964.2014.958072

Harrison T., Morris I., \& Ryan J. (2016). Teaching character in primary schools. Sage.

Hogan, V., \& Daniell, L. (2015). Collaborative teaching and self-study: Engaging student teachers in sociological theory in teacher education. Australian Journal of Teacher Education, 40(4), 1-11. https://doi.org/10.14221/ajte.2015v40n4.1

Jennings, P. A., Snowberg, K. E., Coccia, M. A., \& Greenberg, M. T. (2011). Improving classroom learning environments by cultivating awareness and resilience in education (CARE): Results of two pilot studies. The Journal of Classroom Interaction, 46(1), 37-48. https://doi. org/10.2307/23870550

Knowles, M. S., Holton, E. F., \& Swanson, R. A. (2005). The adult learner. Elsevier.

Ledford, A. T. (2011). Professional development for character education: An evaluation of teachers' sense of efficacy for character education. Scholar-Practitioner Quarterly, 5(3), 256-273. https:// files.eric.ed.gov/fulltext/EJ974354.pdf

Leithwood, K. A., \& Montgomery, D. J. (1980). Evaluating program implementation. Evaluation Review, 4(2), 193-214. https://doi.org/10.1177/0193841X8000400202

Lenhard, W. \& Lenhard, A. (2016). Computation of effect sizes. Psychometrica. https://www. psychometrica.de/effect size.html

Loughran, J. J., Hamilton, M. L., LaBoskey, V. K., \& Russell, T. L. (Eds.). (2004). International handbook of self-study of teaching and teacher education practices. Springer.

Lunenberg, M., \& Samaras, A. P. (2011). Developing a pedagogy for teaching self-study research: Lessons learned across the Atlantic. Teaching and Teacher Education, 27(5), 841-850. https:// doi.org/10.1016/j.tate.2011.01.008

Malmqvist, J., Hellberg, K., Mollas, G., Rose, R., \& Shevlin, M. (2019). Conducting the pilot study: A neglected part of the research process? Methodological findings supporting the importance of piloting in qualitative research studies. International Journal of Qualitative Methods, 18, 1-11. https://doi.org/10.1177/1609406919878341

McDonald, B. L. (2001). Transfer of training in a cultural context: A Cook islands study [Unpublished doctoral dissertation]. Victoria University of Wellington, New Zealand. https://www.wgtn. ac.nz/education/pdf/lex-mcdonald.pdf

Mehta, C. R. \& Patel, N. R. (2012). IBM SPSS exact tests. http://www.sussex.ac.uk/its/pdfs/ SPSS Exact Tests 21.pdf

Midgette, A. J., Ilten-Gee, R., Wong Powers, D., Murata, A., \& Nucci, L. (2018). Using lesson study in teacher professional development for domain-based moral education. Journal of Moral Education, 47(4), 498-518. https://doi.org/10.1080/03057240.2018.1445982 
Nachar, N. (2008). The Mann-Whitney U: A test for assessing whether two independent samples come from the same distribution. Tutorials in Quantitative Methods for Psychology, 4(1), 13-20. https://doi.org/10.20982/tqmp.04.1.p013

Retnowati, E., Ghufron, A., \& Pierawan, A. C. (Eds.). (2018). Character education for 21st century global citizens: Proceedings of the 2nd international conference on teacher education and professional development (INCOTEPD 2017). October 21-22, 2017, Yogyakarta, Indonesia. Routledge.

Rosenberg, G. R. (2018). Moral agency as teaching morally and teaching morality. In T. Harrison, \& D. Walker (Eds.), The Theory and Practice of Virtue Education (pp. 112-125). Routledge.

Samaras, A. P. (2010). Self-study teacher research: Improving your practice through collaborative inquiry. Sage.

Šarić, M., \& Šteh, B. (2017). Critical reflection in the professional development of teachers: Challenges and possibilities. Center for Educational Policy Studies, 7(3), 67-85. https://www. cepsj.si/index.php/cepsj/article/view/288/173

Shukshina, T., Gorshenina, S., Buyanova, I. \& Neyasova, I. (2016). Practice-oriented teachers' training: Innovative approach. International Journal of Environmental and Science Education, 11(16), 9125-9135. https://files.eric.ed.gov/fulltext/EJ1118950.pdf

Surikova, S., \& Pigozne, T. (2018). Transversal competences and character education in Latvia: A needs analysis report. https://dspace.lu.lv/dspace/handle/7/49011

Surikova, S., Pigozne,T., Fernández-González, M. J., \& Stokenberga, I. (2020). Understandings of character and virtue education in Riga: Main findings. In V. Dislere (Ed.), Rural Environment. Education. Personality, 13 (pp. 266-273). Latvia University of Life Sciences and Technologies, Faculty of Engineering, Institute of Education and Home Economics. https://doi.org/10.22616/ REEP.2020.032

Thabane, L., Ma, J., Chu, R., Cheng, J., Ismaila, A., Rios, L. P., Robson, R., Thabane, M., Giangregorio, L., \& Goldsmith, C. H. (2010). A tutorial on pilot studies: The what, why and how. BMC Medical Research Methodology, 10, 1-10. https://doi.org/10.1186/1471-2288-10-1

The Jubilee Centre for Character and Virtues. (2017). A framework for character education in schools. University of Birmingham. http://jubileecentre.ac.uk/userfiles/jubileecentre/pdf/ other-centre-papers/Framework.pdf

The Jubilee Centre for Character and Virtues. (2020). Centre launches Leading Character Education in Schools CPD Programme. University of Birmingham. https://www.jubileecentre.ac.uk/ media/news/article/6677/Centre-Launches-Leading-Character-Education-in-Schools-CPD$\underline{\text { Programme }}$

Van Eekelen, I. M., Vermunt, J. D., \& Boshuizen, H. P. A. (2006). Exploring teachers' will to learn. Teaching and Teacher Education, 22(4), 408-423. https://doi.org/10.1016/j.tate.2005.12.001

Verdeja Muñiz, M., \& García-Sampedro Fernández-Canteli, M. (Eds.) (2018). A needs analysis report: Mapping of teachers' practices and expectations in the field of pupils' intrapersonal competencies and character education in Latvia, Estonia and Spain (Intellectual output No. 1). 
https://www.pzi.lu.lv/fileadmin/user upload/lu portal/projekti/pzi/ARETE/Arete Catalyst Report EN.pdf

Visser, T. C., Coenders, F. G. M., Terlouw, C. \& Pieters, J. (2013). Evaluating a professional development programme for implementation of a multidisciplinary science subject. Journal of Education and Training Studies, 1(2), 89-102. https://doi.org/10.11114/jets.vli2.132

Walan, S., \& Chang Rundgren, S.-N. (2014). Investigating preschool and primary school teachers' self-efficacy and needs in teaching science: A pilot study. Center for Educational Policy Studies Journal, 4(1), 51-67. https://www.cepsj.si/index.php/cepsj/article/view/212/126

Walker, M., Sims, D., \& Kettlewell, K. (2017). Leading character education in schools: Case study report. National Foundation for Educational Research in England and Wales. https://www. nfer.ac.uk/publications/pace02/pace02.pdf

\section{Appendix}

Description of the professional competence development program 'Improving pedagogues' transversal competencies for promoting students' character education and excellence' (the Program)

It would be useful to describe in detail the Program whose feasibility was studied for facilitating the understanding of the research results. The features of the Program can be better understood in the light of the adaptations made to the original program (Arete Catalyst, 2019). A comparison between both programs is presented in Table A-1.

Table A-1

Comparison Between the Original Program and the Program Addressed in This Study

\begin{tabular}{|c|c|c|}
\hline $\begin{array}{l}\text { Program } \\
\text { features }\end{array}$ & Original program 'Arete Catalyst' & The Program addressed \\
\hline Kind of program & $\begin{array}{l}\text { A transnational teacher training } \\
\text { program }\end{array}$ & $\begin{array}{l}\text { A professional competence devel- } \\
\text { opment program }\end{array}$ \\
\hline Target public & In-service teachers & $\begin{array}{l}\text { In-service teachers, career coun- } \\
\text { selors, school leaders }\end{array}$ \\
\hline Academic workload & 32 hours (incl. independent work) & 36 hours (incl. independent work) \\
\hline Program structure & $\begin{array}{l}3 \text { modules: 1) theory; 2) communi- } \\
\text { cation; } 3 \text { ) methodology; an external } \\
\text { project and a final assignment }\end{array}$ & $\begin{array}{l}4 \text { modules: 1) communication; } \\
\text { 2) heory and self-understanding; } \\
\text { 3) methodology; and 4) assess- } \\
\text { ment }\end{array}$ \\
\hline
\end{tabular}




\begin{tabular}{|c|c|c|}
\hline $\begin{array}{l}\text { Intended learning } \\
\text { outcomes (ILOs) }\end{array}$ & $\begin{array}{l}\text { Six domains of ILOs: 1) advanced dis- } \\
\text { ciplinary knowledge and practices; 2) } \\
\text { self-awareness and cognitive skills; } 3 \text { ) } \\
\text { methodological and didactic skills; 4) } \\
\text { communication, adaptive and interac- } \\
\text { tional skills; 5) practicing values; and } \\
\text { 6) transformative skills }\end{array}$ & $\begin{array}{l}\text { Eight ILOs regrouped within } \\
\text { three dimensions: 1) knowledge; } \\
\text { 2) skills; and 3) competence (see } \\
\text { Table A-2) }\end{array}$ \\
\hline Learning activities & $\begin{array}{l}\text { A set of } 10 \text { activities described using a } \\
\text { common template, aligned with ILOs. } \\
\text { Three kinds of activities to be included } \\
\text { (reflective, practical, planning). The } \\
\text { activity set should sum } 32 \text { hours }\end{array}$ & $\begin{array}{l}\text { A set of } 13 \text { activities including } \\
\text { lectures ( } 10 \text { hours), seminars } \\
\text { (discussions, case studies, group } \\
\text { work - } 10 \text { hours); and practical } \\
\text { works (presentations, methodo- } \\
\text { logical materials - } 16 \text { hours) (see } \\
\text { Table A-3) }\end{array}$ \\
\hline Assessment & $\begin{array}{l}\text { Assessment of each activity in refer- } \\
\text { ence to the domains of ILOs }\end{array}$ & $\begin{array}{l}\text { The acquisition of ILOs is assessed } \\
\text { after completing six practical } \\
\text { activities and presenting a project } \\
\text { (see Table A-3) }\end{array}$ \\
\hline
\end{tabular}

In general, the Program kept the structure of the original program (Arete Catalyst, 2019, p. 5), but the authors of the adaptation placed the communication module before the theory and self-understanding module (Table A-3) for facilitating the emergence of a collaborative learning community from the very beginning of the program. The ILOs of the Program were reformulated and regrouped within three dimensions: 1) knowledge; 2) skills; and 3) competence (Table A-2) for complying with the formal requirements of Latvian legislation, as the program had to go through the approval process at the University $\mathrm{X}$ in order to deliver a valid certificate after program completion. 
Table A-2

The ILOs of the Program

\begin{tabular}{|c|c|c|}
\hline Knov & Skills & ence \\
\hline $\begin{array}{l}\text { ILO1: } \mathrm{U} \\
\text { is able } \mathrm{t}\end{array}$ & $\begin{array}{l}\text { ILO4: Is able to listen empathetically and } \\
\text { non-judgmental feedback }\end{array}$ & \multirow{6}{*}{$\begin{array}{l}\text { ILO8: Plans, im- } \\
\text { plements, and } \\
\text { assesses project } \\
\text { implementation } \\
\text { and effectiveness } \\
\text { as well as demon- } \\
\text { strates the results } \\
\text { of transformative } \\
\text { action in the con- } \\
\text { text of a particular } \\
\text { school }\end{array}$} \\
\hline $\begin{array}{l}\text { role of values and per- } \\
\text { sonality in the educa- } \\
\text { tion process }\end{array}$ & $\begin{array}{l}\text { ILO5: Is able to identify and analyze examples } \\
\text { of good practice in Latvia and the world for the } \\
\text { enhancement of pedagogues' transversal com- }\end{array}$ & \\
\hline $\begin{array}{l}\text { ILO2: Understands } \\
\text { opportunities for pro- }\end{array}$ & $\begin{array}{l}\text { petencies in order to promote pupils character } \\
\text { education }\end{array}$ & \\
\hline $\begin{array}{l}\text { motion of personality } \\
\text { growth in the fields of } \\
\text { transversal skill devel- } \\
\text { opment }\end{array}$ & $\begin{array}{l}\text { ILO6: Is able to choose and use relevant value } \\
\text { education and character education methods and } \\
\text { organizational forms to promote student charac- } \\
\text { ter education and value acquisition in accordance }\end{array}$ & \\
\hline \multirow{2}{*}{$\begin{array}{l}\text { ILO3: Understands pri- } \\
\text { mary notions related to } \\
\text { character education }\end{array}$} & & \\
\hline & $\begin{array}{l}\text { ILO7: Is able to formulate specific realistic and } \\
\text { practical suggestions for character education } \\
\text { and value education opportunities adapted to } \\
\text { the school situation, using their transversal } \\
\text { competencies }\end{array}$ & \\
\hline
\end{tabular}

Based on the bank of activities of the original program (Arete Catalyst, 2019, pp. 8-47), the adaptation authors chose and elaborated a set of learning activities, including seminars, practical works, and lectures (Table A-3), which were aligned with one or several ILOs of the Program (the main ILO target of each activity highlighted in bold in Table A-3). Program participants should also implement a character education project at their school and present it at the end of the program. 
Table A-3

Modules, Activities, Academic workload, and Target ILOs of the Program

\begin{tabular}{|c|c|c|c|c|c|c|c|c|c|c|c|}
\hline \multirow{2}{*}{$\begin{array}{l}\text { Mo- } \\
\text { dule }\end{array}$} & \multirow[t]{2}{*}{ Activity name } & \multirow[t]{2}{*}{ Type } & \multirow[t]{2}{*}{ Hours } & \multicolumn{8}{|c|}{ Target ILOs } \\
\hline & & & & 1 & 2 & 3 & 4 & 5 & 6 & 7 & 8 \\
\hline $\mathrm{C}$ & $\begin{array}{l}1.1 \text { Communication and interac- } \\
\text { tional skills }\end{array}$ & $S$ & 4 & & & & $\mathbf{X}$ & & & & $\mathrm{X}$ \\
\hline $\mathrm{C}$ & $\begin{array}{l}1.2 \text { The use of empathic listening } \\
\text { in character education }\end{array}$ & P & 2 & $\mathrm{X}$ & & & $\mathbf{X}$ & & & & \\
\hline $\mathrm{T}$ & $\begin{array}{l}2.1 \text { Self-awareness and self-reflec- } \\
\text { tion skills }\end{array}$ & $S$ & 4 & $\mathbf{X}$ & $\mathrm{X}$ & & & & & & \\
\hline $\mathrm{T}$ & $\begin{array}{l}\text { 2.2 Expressions of values and } \\
\text { coherence at individual and com- } \\
\text { munity level }\end{array}$ & $\mathrm{P}$ & 2 & & $\mathbf{X}$ & & $\mathrm{X}$ & & & & \\
\hline $\mathrm{T}$ & $\begin{array}{l}\text { 3.1 Pedagogues' creativity for im- } \\
\text { plementing a competence-based } \\
\text { approach in the context of Latvi- } \\
\text { an educational content reform }\end{array}$ & $\mathrm{L}$ & 2 & & $\mathbf{X}$ & & & & & & $\mathrm{X}$ \\
\hline $\mathrm{T}$ & $\begin{array}{l}3.2 \text { Identifying examples of good } \\
\text { practice, generating project ideas } \\
\text { for improvement of pedagogues' } \\
\text { creativity for character education }\end{array}$ & $\mathrm{P}$ & 2 & & $\mathrm{X}$ & $\mathrm{X}$ & & $\mathbf{X}$ & & $\mathrm{X}$ & \\
\hline $\mathrm{T}$ & $\begin{array}{l}\text { 4.1 Theory and practice of charac- } \\
\text { ter education }\end{array}$ & $\mathrm{L}$ & 2 & $\mathrm{X}$ & & $\mathbf{X}$ & & & & & \\
\hline $\mathrm{T}$ & $\begin{array}{l}\text { 4.2 Theoretical framework of } \\
\text { character education }\end{array}$ & $\mathrm{P}$ & 2 & & & $\mathrm{X}$ & & $\mathbf{X}$ & & & \\
\hline M & $\begin{array}{l}5.1 \text { Value education and character } \\
\text { education methods and organiza- } \\
\text { tional forms }\end{array}$ & $\mathrm{L}$ & 4 & $\mathrm{X}$ & & & & & $\mathbf{X}$ & & \\
\hline M & $\begin{array}{l}5.2 \text { Methods and organizational } \\
\text { forms for promoting students' } \\
\text { character and virtue development }\end{array}$ & $\mathrm{P}$ & 4 & & $\mathrm{X}$ & & & & $\mathbf{X}$ & & \\
\hline M & $\begin{array}{l}\text { 6.1 Using teachers' transversal } \\
\text { competencies for enhancing stu- } \\
\text { dents' character education }\end{array}$ & $\mathrm{L}$ & 2 & & & & $\mathrm{X}$ & $\mathbf{X}$ & & & \\
\hline M & $\begin{array}{l}6.2 \text { Using teachers transversal } \\
\text { competencies for designing, } \\
\text { elaborating, and implementing a } \\
\text { character education project }\end{array}$ & $\mathrm{P}$ & 4 & & & & & & & $\mathbf{X}$ & $\mathrm{X}$ \\
\hline A & $\begin{array}{l}\text { 7. Collaboration within the prac- } \\
\text { tice and its assessment: presenta- } \\
\text { tion of participants' projects }\end{array}$ & $S$ & 2 & $\mathrm{X}$ & $\mathrm{X}$ & $\mathrm{X}$ & $\mathrm{X}$ & $\mathrm{X}$ & $\mathrm{X}$ & $\mathrm{X}$ & $\mathbf{x}$ \\
\hline
\end{tabular}

Note. Module: C - communication; T - theory and self-understanding; M - methodology; A - assessment. Type of activity: S - seminar (10 hours); P - practical work (16 hours); L - lecture (10 hours). ILOs: For a detailed description see Table A-2. 
The assessment of the eight ILOs (Table A-2) was aligned with the activities of the Program. The final evaluation of the program took into account the assessment of each activity, in particular of the activities of the type 'practical work' (labelled with P in Table A-3, column 3), which had to be completed independently, and the final project.

For example, the ILO1 was strongly aligned with the practical work 1.2 ('The use of empathic listening in character education'), and also with the seminar 2.1 ('Self-awareness and self-reflection skills'), the lectures 4.1 ('Theory and practice of character education') and 5.1 ('Value education and character education methods and organizational forms') and the final project (see details for the alignment of each ILO and activity in Table A-3). The ILO8 (competence) was evaluated after presenting the final project, and integrated all the knowledge and skills of the other ILOs.

All the seminars and lectures had to be implemented in direct presence modality. The six practical works had to be done by participants independently at home or in the workplace. They were formulated as follows: 1) In an individually chosen communicative situation, purposefully apply empathetic listening skills and perform self-reflection (Table A-3, activity 1.2); 2) Gather information in your educational community on important topics related to the understanding of values (Table A-3, activity 2.2); 3) Read the Erasmus+ project's 'Arete Catalyst' report (Verdeja Muñiz \& García-Sampedro Fernández-Canteli, 2018), to identify examples of good practice in Latvia and the world, generate and offer project ideas for the enhancement of teachers' creativity for character education (Table A-3, activity 3.2); 4) Read the electronic materials offered on character education, improve your understanding of the primary notions related to character education and its interpretation, to discuss about the context of transversal skills in relation to the project School2030 (Table A-3, activity 4.2); 5) Choose and analyze relevant value education and character education methods and organization forms for promoting students' character and virtue education in accordance with the context and needs of your school (Table A-3, activity 5.2); and 6) Design and implement in practice a character education project at school (Table A-3, activity 6.2).

The formal requirements for completing the Program were the active participation in lectures and seminars (discussions, situation analysis, group work), the implementation of the students' independent works (presentations, elaboration of methodological materials), and the design, implementation, and presentation of the character education project. 


\title{
Mokytojų profesinio tobulëjimo programa asmenybès ugdymui: igyvendinamumo tyrimas Latvijoje
}

\author{
Svetlana Surikova ${ }^{1}$, Manuel Joaquín Fernández González², Tamara Pigozne ${ }^{3}$, \\ Ieva Margeviča-Grinberga ${ }^{4}$, Dita Nimante ${ }^{5}$, Ieva Stokenberga ${ }^{6}$ \\ 1 Latvijos universitetas, Edukologijos, psichologijos ir meno fakultetas, Pedagogikos mokslinis institutas, Imanto 7 linija 1, \\ LV-1083, Ryga, Latvija, svetlana.surikova@lu.lv \\ 2 Latvijos universitetas, Edukologijos, psichologijos ir meno fakultetas, Pedagogikos mokslinis institutas, Imanto 7 linija 1, \\ LV-1083, Ryga, Latvija, manuels.fernandezs@lu.lv \\ 3 Latvijos universitetas, Edukologijos, psichologijos ir meno fakultetas, Pedagogikos mokslinis institutas, Imanto 7 linija 1, \\ LV-1083, Ryga, Latvija, tamara.pigozne@lu.lv \\ 4 Latvijos universitetas, Edukologijos, psichologijos ir meno fakultetas, Mokytojų rengimo katedra, Imanto 7 linija 1 , \\ LV-1083, Ryga, Latvija, ievam@lu.lv \\ 5 Latvijos universitetas, Edukologijos, psichologijos ir meno fakultetas, Edukologijos ir pedagoginių inovacijų katedra, Imanto \\ 7 linija 1, LV-1083, Ryga, Latvija, dita.nimante@lu.lv \\ 6 Latvijos universitetas, Edukologijos, psichologijos ir meno fakultetas, Psichologijos katedra, Imanto 7 linija 1, LV-1083, \\ Ryga, Latvija, ieva.stokenberga@lu.lv
}

\section{Santrauka}

Šis straipsnis prisideda prie mokymo programų tyrimų. Jame analizuojama nauja mokytojų profesinio tobulejimo programa, skirta asmenybès ugdymui mokykloje. Tyrimo tikslas - nustatyti šios programos igyvendinamumą Latvijos kontekste vadovaujantis tyrimo klausimu „Koks yra bendras programos igyvendinamumas atsižvelgiant ị dalyvių ir vykdytojų nuomonę?". Taikant mišrų metodą, 2019 m. pavasarị dvidešimt keturi mokytojai ir keturi mokytojų rengejai, dalyvaujantys igyvendinamumo tyrime, ịvertino programą, atsižvelgdami ị bendruosius jos aspektus (pvz., jos sutelktumą, medžiagą ir metodiką) ir pagrindinius komponentus (pvz., mokymosi rezultatus, struktūrą, veiklą ir trukmę). Tam buvo naudojamas klausimynas. Savarankiško mokymosi bendradarbiaujant metodas buvo naudojamas siekiant ištirti tiek vykdy tojų, tiek dalyvių suvokimą apie programos igyvendinamumą ir pagrindines jos stipriąsias bei silpnąsias puses. Rezultatai atskleidžia, kad dauguma respondentų buvo patenkinti programos igyvendinamumu, ypač programos medžiaga, veikla, numatytais mokymosi rezultatais, metodika, trukme ir nuoseklumu.

Taip pat buvo nustatyta, kad mokymosi dalyviai buvo kritiškesni nei vykdytojai visu programos dalių (išskyrus programos medžiagą) atžvilgiu. Remiantis dviem fokusuotų grupių diskusijomis apie igyvendinamumo tyrimo rezultatus, buvo pateikti pasiūlymai tolesniam programos ịgyvendinimui dèl papildymo, įvadinio programos kurso, struktūros, jos pristatymo grafiko ir internetinès aplinkos galimybių panaudojimo.

Esminiai žodžiai: asmenybès ugdymas, igyvendinamumo tyrimas, programos pritaikymas, programos igyvendinamumas ir vientisumas, mokytoju profesinis tobulejimas. 